\title{
PERFORMANCE ANALYSIS OF SUSTAINABLE AGROTOURISM IN LEBAKMUNCANG VILLAGE
}

\author{
Ulya Rahmah, Endah Djuwendah \\ Padjadjaran University, Indonesia \\ ulyarahmah24@gmail.com
}

\begin{abstract}
Agro-tourism in Lebakmuncang Village has a selling value in the form of natural potential, agriculture, arts, crafts, and traditional culinary processing typical of the village. This agro-tourism has the potential of a sustainable tourism object. The purpose of this research is to measure the performance of agro-tourism from the perspective of naturalness, uniqueness, workforce involvement, land-use optimization, area arrangement, and education. The research design used is descriptive quantitative with a survey method. Collecting data using observation, questionnaires, interviews, and literature studies. The research data were analyzed using descriptive analysis with a Likert scale. The results showed that agro-tourism performance on naturalness was in the very good category. Meanwhile, the performance of agro-tourism towards uniqueness, the involvement of labor, optimization of land use, zoning, and education are categorized as good.
\end{abstract}

Keywords: Sustainable Agro-tourism; Performance analysis; Lebakmuncang Village.

\section{INTRODUCTION}

Tourism is an alternative that has an important role in the economic development of a region. Tourism is said to be everything related to travel to carry out various tourist activities provided by several parties, to travel to a place (Maesari, 2018). Based on Law No. 10 of 1990 concerning Tourism, tourism is a variety of tourist activities and is supported by various services and facilities provided by the community, businessmen, government, and local governments. This was also expressed by the Minister of Tourism, Arief Yahya (2017), who said the tourism sector could help increase GDP, generate foreign exchange, and create jobs (in Putri, 2017). Tourism foreign exchange income has always increased from 2013 to 2016. The tourism sector in 2013 - 2015 was ranked fourth as the highest foreign exchange income, while in 2016 it was ranked second (Badan Pusat Statistik (BPS) and Pusat Data and Informasi (Pusdatin) Kementerian Pariwisata., 2018). 
Table 1. Indonesia's Foreign Exchange Earnings by Business Field 2013 - 2016 Electrical Tools

\begin{tabular}{|c|l|c|c|c|c|}
\hline \multirow{2}{*}{ No } & \multirow{2}{*}{ Type of Commodity } & \multicolumn{4}{|c|}{ Value (million USD) } \\
\cline { 3 - 6 } & & 2013 & 2014 & 2015 & 2016 \\
\hline 1 & Oil and gas & 32,633 & 30,318 & 18,574 & 13,105 \\
\hline 2 & Coal & 22,759 & 18,697 & 14,717 & 12,898 \\
\hline 3 & CPO & 16,787 & 18,615 & 16,427 & 15,965 \\
\hline 4 & Tourism & $\mathbf{1 0 , 0 5 4}$ & $\mathbf{1 1 , 1 6 6}$ & $\mathbf{1 2 , 2 2 5}$ & $\mathbf{1 3 . 5 6 8}$ \\
\hline 5 & Processed Rubber & 6,706 & 6,259 & 3,564 & 3,242 \\
\hline 6 & Apparel & 6,216 & 7,450 & 6,410 & 6,229 \\
\hline 7 & Electrical Tools & 5,104 & 7,021 & 4,510 & 4,561 \\
\hline 8 & Chemical material & 4,124 & 6,486 & 3,174 & 3,700 \\
\hline 9 & Paper & 3,723 & 5,379 & 3,546 & 4,032 \\
\hline 10 & Textiles & 1,948 & 3,853 & 1,927 & 1,848 \\
\hline 11 & Processed Wood & 1,203 & 3,780 & 1,352 & 1,279 \\
\hline 12 & Jewelry & 202 & 3,914 & 3,319 & 4,119 \\
\hline
\end{tabular}

Source : BPS and Pusdatin Kemenpar

The current tourism trend has changed from general tourism to special interest tourism or it can be said that nature tourism is more towards maintaining environmental sustainability. Special interest tourism is tourism that offers activities that are not usually carried out by tourists in general or tours with special skills or special interests. Special interest tourism attractions, namely utilizing nature and culture as a background, are also created with specific challenges and concerns (Ismayanti, 2010). Where one example of special interest tourism is agrotourism.

West Java Province is a potential area for agro-tourism development. This can be seen from the trend of visitors, which shows that the number of visits by foreign and domestic tourists from 2018 to 2019 has always increased (Figure 1). Agro-tourism is a combination of tourism and agriculture or plantations combined to become an attractive destination for people to do activities in the plantation environment (PPID Distanhor Jabar, 2019). Also, agro-tourism is also a tourism business whose development base is on agriculture and rural lifestyles (Kristiana \& Theodora, 2018). Where one example is Agro-tourism in the Tourism Village. 


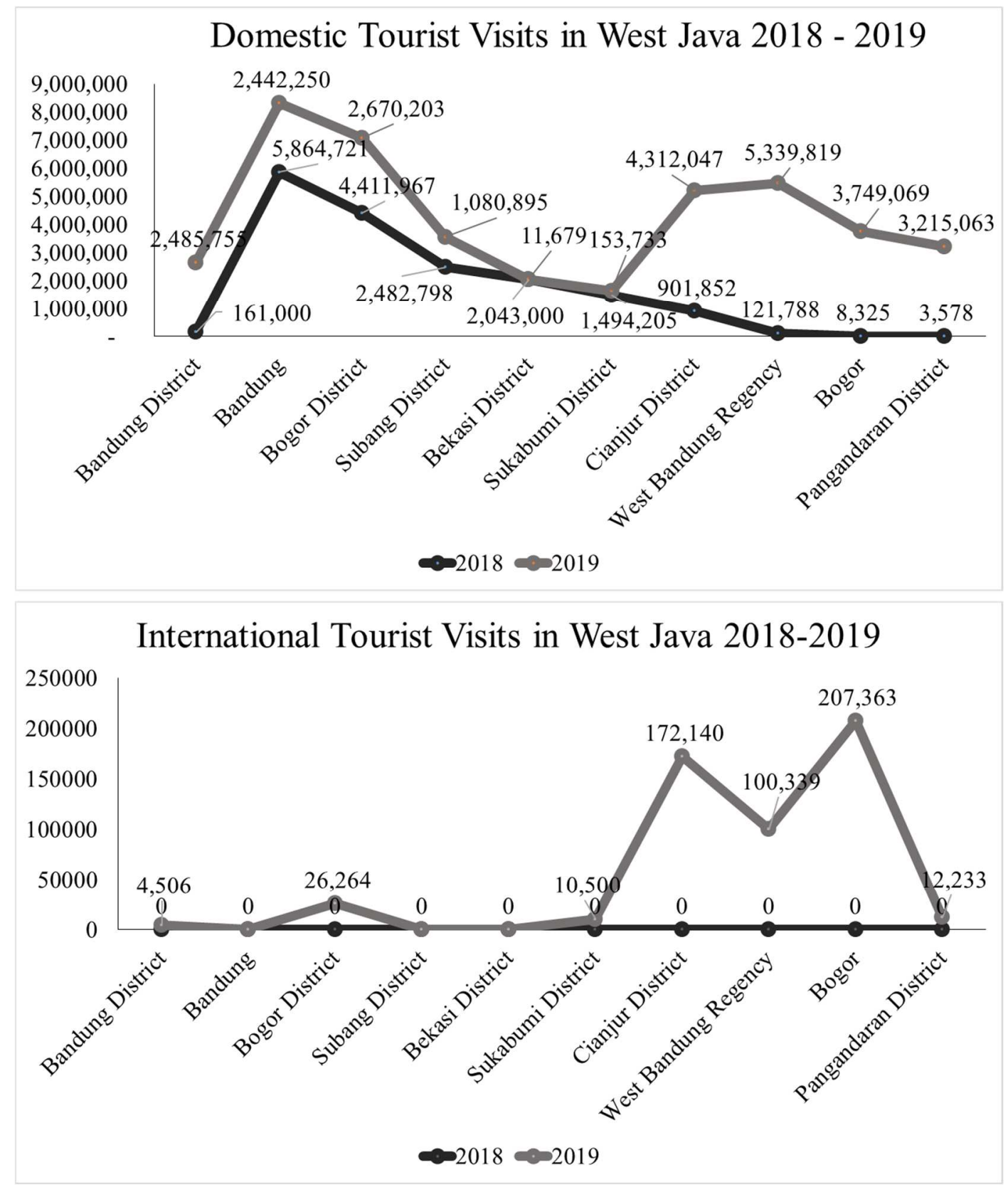

Figure 1. Number of Tourist Visits in West Java in 2018 - 2019

Source: Department of Tourism and Culture of West Java Province

Bandung Regency is one of the areas that is the destination of tourists from both foreign and domestic. Jabarprov stated that there are many tourist areas in Bandung Regency that have the potential to develop agro-tourism. The Ciwidey area can be said to be one of the favorite places to travel because the Ciwidey area offers so many choices of tourist attractions. One of the several Tourism Villages in Ciwidey District that has the potential to develop agro-tourism is located in the Lebakmuncang Tourism Village. 
Lebakmuncang Tourism Village, Ciwidey District has natural and cultural beauty that is still beautiful. This area is famous for its green, natural conditions, and some indigenous people live in the area. In the beginning, Lebakmuncang Tourism Village was established from the initiative of the local community, namely RW 18 and RW 25. Over time, the village head began to strengthen this tourist village with the issuance of a Decree of the Regent of Lebakmuncang Tourism Village by the Bandung Regency government. As recorded in the Bandung Regent Decree No. 556.42 / Kep.71-Dispopar / 2011, ten villages are tourism villages. One of them is the Lebakmuncang Tourism Village which is included in the type of agro-tourism. It is said to be agro-tourism because Lebakmuncang Tourism Village has a selling value in the form of natural potential, agriculture, arts, handicrafts, and processing of traditional culinary specialties from the village. In this case, agrotourism in Lebakmuncang Tourism Village has the potential to be a sustainable tourism object.

In this case, the development of Agro-tourism in Lebakmuncang Tourism Village has not been optimal, it is also shown in the data from the Youth and Sports Tourism Office (2020), namely the status of Agro-tourism in Lebakmuncang Tourism Village is still not advanced. According to Kamal \& Suhirman (2019) in their development efforts, Lebakmuncang Tourism Village is constrained by the lack of synergy between the parties involved (stakeholders) who have certain interests and strengths, so based on information from Dispopar, Lebakmuncang Tourism Village is not yet a managed tourism village. well, and based on the survey results, the group of workers (POKJA) has not been able to independently develop everything related to tourism activities. In the development of agro-tourism, several factors are taken into consideration such as naturalness, uniqueness, scarcity, optimization of land use, the involvement of labor, (Syamsu, 2001), and education. If planning ethics can be implemented properly, it is hoped that the role of a tourist attraction will be felt for local communities (Junaedi \& Utama, 2017).

The purpose of this study is to measure the performance of agro-tourism from the perspective of naturalness, uniqueness, workforce involvement, optimization of land use, zoning, and education. This research needs to be done because no one has raised the issue of agro-tourism performance from an educational perspective. Similar research was conducted by Syamsu (2001) entitled Ethics of Planning for Agro-tourism Area of Salak Pondoh Sleman Yogyakarta and research conducted by Utama (2004) entitled Ethics of Agro-tourism Development in the Area Around the Tamblingan Lake Nature Tourism Park. The difference from previous studies is that there is no indicator from an educational perspective. Meanwhile, education is important to look at because a good education will create a sustainable agrotourism performance.

\section{METHODOLOGY}

This research was conducted in the agro-tourism area of Lebakmuncang Tourism Village, Ciwidey District, Bandung Regency, West Java. The research design used is descriptive quantitative. According to Sugiyono (2013), the quantitative research method is a theory-based research method used to examine populations or samples in certain research areas. The research technique used is survey research. According to Sugiyono (2013), the survey method is research 
conducted using a questionnaire as a research tool with data that is learned from a sample taken from the population.

The data used in this study consisted of two types, namely primary data and secondary data. Primary data obtained from observations/observations, filling out questionnaires, and results of direct interviews with village officials and a group of workers (pokja) Lebakmuncang Tourism Village. Meanwhile, secondary data were obtained from several literature studies such as books, articles, and journals. Apart from that, it was obtained from related parties, both from Lebakmuncang Village, the West Java Province Tourism and Culture Office, and the Central Statistics Agency (BPS).

Sampling was done by taking a sample from a population. The population in this study was Lebakmuncang Village involved in agro-tourism activities, amounting to 101 people divided into 5 community groups. Then by using the Slovin formula Umar (2005) with an error limit of 10\%, 51 samples will be obtained. The sampling technique uses probability sampling techniques because all members of the population have the same opportunity to become respondents. The probability sampling technique used is disproportionate stratified random sampling, which is defined as a sampling technique carried out when the properties or elements in the population are not homogeneous and stratified less or disproportionately.

The data analysis used in this study is descriptive analysis to analyze the results of each instrument in narrative form and summarized in tabulation and score level calculations (Riduwan, 2007), where the data is in the form of a Likert scale ( 5 criteria) in the study then concluded the score is based on the score level formula.

1. Determine the minimum index value $=\min$ score $x \sum$ questions $x \sum$ respondent

2. Determine the maximum index value $=\max$ score $x$ Equestions $x \sum$ respondents

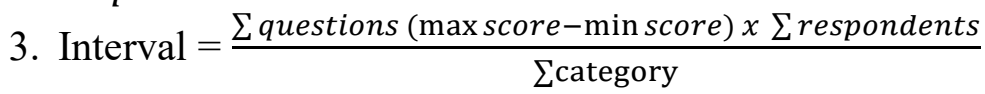

\section{RESULTS AND DISCUSSION}

Perceptions of the performance of sustainable agro-tourism are divided into six categories, namely naturalness, uniqueness, workforce involvement, land-use optimization, zoning (Syamsu, 2001 in Utama, 2004), and education. Perceptions of Naturalness

Based on Table 2, perceptions of naturalness received various values from the respondents. The results of the calculation of the researcher's analysis on naturalness were the minimum index of 153, the maximum index of 765, and the interval of 204. Respondents' perceptions of naturalness got a very good score with a score of 640. This is evidenced by the processing results of three question indicators consisting of natural beauty, natural beauty, and natural comforts that support the development of agro-tourism. Environmental conditions that are still beautiful and natural, Lebakmuncang Village offers an agro-tourism program in the form of a tourist village. Where this tourism village offers the naturalness of a village both in terms of socio-culture, customs, daily life, traditional architecture, village spatial structure which is presented in a form of integration of agro-tourism 
components. According to Firdausyah (2017), the attraction of tourists visiting tourist attractions for recreational activities and having fun is because of the beautiful scenery that is attractive to enjoy. Also, the Lebakmuncang Tourism Village area needs to be maintained naturally so that the concept of sustainable tourism is realized for future generations.

Table 2. Results of the Perception of Naturalness Research

\begin{tabular}{|c|l|c|c|c|c|c|c|}
\hline \multirow{2}{*}{ No. } & \multicolumn{1}{|c|}{ Indicator } & $\begin{array}{c}\text { Strongly } \\
\text { Disagree } \\
(1)\end{array}$ & $\begin{array}{c}\text { Disagree } \\
(2)\end{array}$ & $\begin{array}{c}\text { Not } \\
\text { Agree } \\
(3)\end{array}$ & $\begin{array}{c}\text { Agree } \\
(4)\end{array}$ & $\begin{array}{c}\text { Strongly } \\
\text { Agree } \\
(5)\end{array}$ & $\begin{array}{c}\text { Total } \\
\text { Score }\end{array}$ \\
\hline $\begin{array}{l}\text { There is } \\
\text { natural nature } \\
\text { to support the } \\
\text { development } \\
\text { of agro- } \\
\text { tourism }\end{array}$ & 0 & 0 & 10 & 31 & 10 & 204 \\
\hline 2 & $\begin{array}{l}\text { There is a } \\
\text { natural beauty } \\
\text { that supports } \\
\text { the } \\
\text { development } \\
\text { of agro- } \\
\text { tourism }\end{array}$ & 0 & 0 & 3 & 34 & 14 & 215 \\
\hline $\begin{array}{l}\text { There is } \\
\text { natural } \\
\text { comfort to } \\
\text { support the } \\
\text { development } \\
\text { of agro- } \\
\text { tourism }\end{array}$ & 0 & 0 & 1 & 32 & 18 & 221 \\
\hline Total Frequency & 0 & 0 & 14 & 97 & 42 & 640 \\
\hline Percentage (\%) & 0 & 0 & 9.15 & 63.40 & 27.45 & 100 \\
\hline
\end{tabular}

Perceptions of Uniqueness

Based on Table 3 perceptions of uniqueness get various values from the respondents. The results of the calculation of the researcher's analysis on uniqueness, namely the minimum index of 153 , the maximum index of 765 , and the interval of 204. Respondents' perceptions of uniqueness are in a good position with a score of 538. However, the figures obtained are not satisfactory. This is because there are no natural resources that are different from other tourism. According to DISPARBUD (2018), one of the criteria that must be owned by a tourist village is to have a unique potential and a unique tourist attraction in the form of a rural natural environment and the socio-cultural life of the community. Lebakmuncang Tourism Village needs to add agricultural commodities, because actually the agricultural potential in Lebakmuncang Village can still be explored and expanded again to be used as a tourist attraction. Even so, the uniqueness of the Lebakmuncang Tourism Village area with its cool temperature and beautiful natural 
scenery must be maintained and preserved so that there is no exploitation for momentary interests.

Table 3. Research Results on Perceptions of Uniqueness

\begin{tabular}{|c|c|c|c|c|c|c|c|}
\hline \multirow[b]{2}{*}{ No. } & \multirow[b]{2}{*}{ Indicator } & \multicolumn{5}{|c|}{ Criteria } & \multirow[b]{2}{*}{$\begin{array}{l}\text { Total } \\
\text { Score }\end{array}$} \\
\hline & & $\begin{array}{c}\text { Strongly } \\
\text { Disagree } \\
(1)\end{array}$ & $\begin{array}{c}\text { Disagree } \\
\text { (2) }\end{array}$ & $\begin{array}{c}\text { Not } \\
\text { Agree } \\
(3)\end{array}$ & $\begin{array}{c}\text { Agree } \\
\text { (4) }\end{array}$ & $\begin{array}{l}\text { Strongly } \\
\text { Agree } \\
\text { (5) }\end{array}$ & \\
\hline 1 & $\begin{array}{l}\text { Unique } \\
\text { community } \\
\text { traditions }\end{array}$ & 0 & 0 & 10 & 36 & 5 & 199 \\
\hline 2 & $\begin{array}{l}\text { Some customs } \\
\text { support the } \\
\text { development } \\
\text { of agro- } \\
\text { tourism }\end{array}$ & 0 & 0 & 21 & 28 & 2 & 185 \\
\hline 3 & $\begin{array}{l}\text { There are } \\
\text { natural } \\
\text { resources that } \\
\text { are different } \\
\text { from other } \\
\text { tours }\end{array}$ & 0 & 9 & 33 & 8 & 1 & 154 \\
\hline \multicolumn{2}{|c|}{ Total Frequency } & 0 & 9 & 64 & 72 & 8 & 538 \\
\hline \multicolumn{2}{|c|}{ Percentage (\%) } & 0 & 5.88 & 41.83 & 47.06 & 5.23 & 100 \\
\hline
\end{tabular}

Perceptions of Labor Involvement

Based on Table 4 perceptions Respondents received various scores on the involvement of the workforce. The results of the calculation of the researcher's analysis on labor engagement are the minimum index of 153, the maximum index of 765, and the interval of 204. Respondents' perceptions of workforce engagement are in a good position with a score of 509. In this case, the figures obtained are still not satisfactory because communities involved in agro-tourism activities can still be improved. With the existence of a tourist attraction, it is hoped that it will provide benefits to the involvement of the workforce for people who are in the tourist area or the people of Lebakmuncang Village in general.

Table 4. Research Results on Perceptions of Labor Involvement

\begin{tabular}{|c|l|c|c|c|c|c|c|}
\hline \multirow{2}{*}{ No. } & \multicolumn{1}{|c|}{ Indicator } & $\begin{array}{c}\text { Strongly } \\
\text { Disagree } \\
(1)\end{array}$ & $\begin{array}{c}\text { Disagree } \\
(2)\end{array}$ & $\begin{array}{c}\text { Not } \\
\text { Agree } \\
(3)\end{array}$ & $\begin{array}{c}\text { Agree } \\
(4)\end{array}$ & $\begin{array}{c}\text { Strongly } \\
\text { Agree } \\
(5)\end{array}$ & $\begin{array}{c}\text { Total } \\
\text { Score }\end{array}$ \\
\hline 1 & $\begin{array}{l}\text { The involved } \\
\text { workforce in } \\
\text { agro-tourism } \\
\text { development }\end{array}$ & 0 & 2 & 16 & 26 & 7 & 191 \\
\hline 2 & $\begin{array}{l}\text { The workforce } \\
\text { has agro- } \\
\text { tourism }\end{array}$ & 0 & 3 & 33 & 15 & 0 & 165 \\
\hline
\end{tabular}




\begin{tabular}{|c|l|c|c|c|c|c|c|}
\hline & $\begin{array}{l}\text { development } \\
\text { experience }\end{array}$ & & & & & & \\
\hline 3 & $\begin{array}{l}\text { The workforce } \\
\text { has emotional } \\
\text { intelligence in } \\
\text { developing } \\
\text { agro-tourism }\end{array}$ & 0 & 4 & 43 & 4 & 0 & 153 \\
\hline Total Frequency & 0 & 9 & 92 & 45 & 7 & 509 \\
\hline Percentage (\%) & 0 & 5.88 & 60.13 & 29.41 & 4.58 & 100 \\
\hline
\end{tabular}

Perception of Optimizing Land Use

Based on Table 5 perceptions of optimization of use land received varying values from respondents. The results of the calculation of the researcher's analysis on the optimization of land use are the minimum index of 204, the maximum index of 1.020, and the interval of 272. Respondents' perceptions of optimizing land use are in a good position with a score of 644. Optimizing land use in the area of agrotourism development objects is by educating community and carry out a movement to optimize drainage or water channels, carry out reforestation and construction of terraces.

Table 5. Research Results on Perceptions of Optimizing Land Use

\begin{tabular}{|c|l|c|c|c|c|c|c|}
\hline \multirow{2}{*}{ No. } & \multicolumn{1}{|c|}{ Indicator } & $\begin{array}{c}\text { Strongly } \\
\text { Disagree } \\
(1)\end{array}$ & $\begin{array}{c}\text { Disagree } \\
(2)\end{array}$ & $\begin{array}{c}\text { Not } \\
\text { Agree } \\
(3)\end{array}$ & $\begin{array}{c}\text { Agree } \\
(4)\end{array}$ & $\begin{array}{c}\text { Strongly } \\
\text { Agree } \\
(5)\end{array}$ & $\begin{array}{c}\text { Total } \\
\text { Score }\end{array}$ \\
\hline $\begin{array}{l}\text { There is land } \\
\text { conservation } \\
\text { in the object of } \\
\text { agrotourism } \\
\text { development }\end{array}$ & 1 & 15 & 24 & 8 & 3 & 150 \\
\hline 2 & $\begin{array}{l}\text { There are } \\
\text { activities to } \\
\text { optimize } \\
\text { drainage in the } \\
\text { object of } \\
\text { agrotourism } \\
\text { development }\end{array}$ & 0 & 10 & 9 & 26 & 6 & 181 \\
\hline 3 & $\begin{array}{l}\text { There are } \\
\text { reforestation } \\
\text { activities in } \\
\text { the object of } \\
\text { agrotourism } \\
\text { development }\end{array}$ & 2 & 13 & 22 & 8 & 6 & 156 \\
\hline 4 & $\begin{array}{l}\text { There is a } \\
\text { terrace }\end{array}$ & 0 & 10 & 28 & 12 & 1 & 157 \\
\hline Total Frequency & 3 & 48 & 83 & 54 & 16 & 644 \\
\hline Percentage (\%) & 1.47 & 23.53 & 40.69 & 26.47 & 7.84 & 100 \\
\hline
\end{tabular}


Perception Regarding Area Arrangement

Based on Table 6, perceptions of area arrangement received various values from respondents. The results of the calculation of the researcher's analysis on area arrangement are a minimum index of 459, a maximum index of 2,295 and an interval of 612. Arrangement of tourist areas is an effort to build, improve, or create more effective and efficient tourist arrangements and activities (Firdausyah, 2017). Respondents' perceptions of the area arrangement are in a good position with a score of 1,586. However, the score results need to be improved, such as adding facilities for tourists (information centers and service places), places to buy souvenirs, procurement of self-picking tourism gardens (own harvest).

Table 6. Research Results on Perceptions of Area Arrangement

\begin{tabular}{|c|c|c|c|c|c|c|c|}
\hline \multirow[b]{2}{*}{ No. } & \multirow[b]{2}{*}{ Indicator } & \multicolumn{5}{|c|}{ Criteria } & \multirow[b]{2}{*}{$\begin{array}{l}\text { Total } \\
\text { Score }\end{array}$} \\
\hline & & $\begin{array}{c}\text { Strongly } \\
\text { Disagree } \\
(1)\end{array}$ & $\begin{array}{l}\text { Disagree } \\
\text { (2) }\end{array}$ & $\begin{array}{c}\text { Not } \\
\text { Agree } \\
(3)\end{array}$ & $\begin{array}{l}\text { Agree } \\
\text { (4) }\end{array}$ & $\begin{array}{l}\text { Strongly } \\
\text { Agree } \\
(5)\end{array}$ & \\
\hline 1 & $\begin{array}{l}\text { There is an on } \\
\text { the farm area }\end{array}$ & 0 & 0 & 0 & 16 & 35 & 239 \\
\hline 2 & $\begin{array}{l}\text { The existence } \\
\text { of farms that } \\
\text { support agro- } \\
\text { tourism } \\
\text { development }\end{array}$ & 0 & 0 & 2 & 35 & 14 & 216 \\
\hline 3 & $\begin{array}{l}\text { The layout of } \\
\text { the location } \\
\text { for agricultural } \\
\text { cultivation }\end{array}$ & 0 & 0 & 8 & 35 & 8 & 204 \\
\hline 4 & $\begin{array}{l}\text { There is an } \\
\text { agro-industrial } \\
\text { layout for } \\
\text { agro-tourism } \\
\text { development }\end{array}$ & 32 & 14 & 5 & 0 & 0 & 75 \\
\hline 5 & $\begin{array}{l}\text { The existence } \\
\text { of an off-farm } \\
\text { farming area }\end{array}$ & 0 & 0 & 0 & 28 & 23 & 227 \\
\hline 6 & $\begin{array}{l}\text { There is a } \\
\text { location for } \\
\text { performing } \\
\text { arts for the } \\
\text { development } \\
\text { of agro- } \\
\text { tourism }\end{array}$ & 0 & 0 & 0 & 24 & 27 & 231 \\
\hline 7 & $\begin{array}{l}\text { There is a } \\
\text { place for } \\
\text { selling agro- } \\
\text { industrial } \\
\text { products }\end{array}$ & 30 & 12 & 8 & 1 & 0 & 82 \\
\hline 8 & There is a & 4 & 10 & 30 & 6 & 1 & 143 \\
\hline
\end{tabular}




\begin{tabular}{|c|l|c|c|c|c|c|c|}
\hline $\begin{array}{l}\text { place to } \\
\text { service the } \\
\text { needs of } \\
\text { tourists }\end{array}$ & 0 & 0 & 36 & 14 & 1 & 169 \\
\hline $\begin{array}{l}\text { The existence } \\
\text { of natural } \\
\text { tourism that } \\
\text { supports the } \\
\text { development } \\
\text { of agro- } \\
\text { tourism }\end{array}$ & 66 & 36 & 89 & 159 & 109 & 1586 \\
\hline Total Frequency & 14.38 & 7.84 & 19.39 & 34.64 & 23.75 & 100 \\
\hline Percentage (\%)
\end{tabular}

Perceptions of Education

Based on Table 7 perceptions of education received varying scores from the respondents. The results of the calculation of the researcher's analysis on education are the minimum index of 357, the maximum index of 1.785, and the interval of 476. The results of the perception of education show that the value is in the good category, the respondent's assessment with a score of 1.167. In this case, Lebakmuncang Tourism Village is good enough because it has utilized agriculture (agro) as a tourist attraction and combines agricultural activities and tourism activities. In addition to selling services to meet consumer needs for beautiful scenery and fresh air, it can also act as an educational medium for the community and visitors, ranging from agricultural education to cultural conservation activities. Even though it is in the good category, in Table 17 it can be seen that the tourism objects are still lacking in terms of environmental conservation education. Waste processing activities have not been implemented at tourist sites. Therefore, there must be an increase in environmental conservation activities.

Table 7. Research Results on Perceptions of Education

\begin{tabular}{|c|l|c|c|c|c|c|c|}
\hline \multirow{2}{*}{ No. } & \multicolumn{1}{|c|}{ Indicator } & $\begin{array}{c}\text { Strongly } \\
\text { Disagree } \\
(1)\end{array}$ & $\begin{array}{c}\text { Disagree } \\
(2)\end{array}$ & $\begin{array}{c}\text { Not } \\
\text { Agree } \\
(3)\end{array}$ & $\begin{array}{c}\text { Agree } \\
(4)\end{array}$ & $\begin{array}{c}\text { Strongly } \\
\text { Agree } \\
(5)\end{array}$ & $\begin{array}{c}\text { Total } \\
\text { Score }\end{array}$ \\
\hline 1 & $\begin{array}{l}\text { There is } \\
\text { agricultural } \\
\text { cultivation } \\
\text { education } \\
\text { which is a } \\
\text { tourist } \\
\text { attraction }\end{array}$ & 0 & 2 & 6 & 23 & 20 & 214 \\
\hline 2 & $\begin{array}{l}\text { There is } \\
\text { environmental } \\
\text { conservation } \\
\text { education in }\end{array}$ & 2 & 4 & 17 & 28 & 0 & 173 \\
\hline
\end{tabular}




\begin{tabular}{|c|c|c|c|c|c|c|c|}
\hline & tourist areas & & & & & & \\
\hline 3 & $\begin{array}{l}\text { There are } \\
\text { educational } \\
\text { activities for } \\
\text { sorting organic, } \\
\text { inorganic, and } \\
\text { hazardous } \\
\text { waste }\end{array}$ & 19 & 24 & 6 & 2 & 0 & 93 \\
\hline 4 & $\begin{array}{l}\text { There are } \\
\text { waste } \\
\text { processing } \\
\text { educational } \\
\text { activities }\end{array}$ & 21 & 21 & 6 & 3 & 0 & 93 \\
\hline 5 & $\begin{array}{l}\text { There are local } \\
\text { cultural } \\
\text { conservation } \\
\text { activities to } \\
\text { preserve a } \\
\text { culture }\end{array}$ & 0 & 0 & 0 & 28 & 23 & 227 \\
\hline 6 & $\begin{array}{l}\text { There are } \\
\text { traditional food } \\
\text { processing } \\
\text { activities to } \\
\text { preserve a } \\
\text { culture }\end{array}$ & 0 & 0 & 0 & 27 & 24 & 228 \\
\hline 7 & $\begin{array}{l}\text { There are local } \\
\text { handicraft } \\
\text { processing } \\
\text { activities to } \\
\text { preserve a } \\
\text { culture }\end{array}$ & 3 & 18 & 21 & 8 & 1 & 139 \\
\hline \multicolumn{2}{|c|}{ Total Frequency } & 45 & 69 & 56 & 119 & 68 & 1167 \\
\hline \multicolumn{2}{|c|}{ Percentage (\%) } & 12.61 & 19.33 & 15.69 & 33.33 & 19.05 & 100 \\
\hline
\end{tabular}

\section{CONCLUSION}

Agro-tourism performance in Lebakmuncang Village towards naturalness is in the very good category. Where this tourism village offers the naturalness of a village both in terms of socio-culture, customs, daily life, traditional architecture, village spatial structure which is presented in a form of integration of agro-tourism components. Meanwhile, the performance of agro-tourism towards uniqueness, the involvement of labor, optimization of land use, zoning, and education are categorized as good. In this case, the development of Agro-tourism in Lebakmuncang Tourism Village has not been maximized, where Lebakmuncang Tourism Village does not yet have natural resources that are different from other tourism, people involved in agro-tourism activities can still be improved, besides that they cannot optimize land and area use and education for agro-tourism 
development. This research needs to be done because no one has raised the issue of agro-tourism performance from an educational perspective.

\section{ACKNOWLEDGEMENT}

To improve the quality of service or performance of agro-tourism in Lebakmuncang Tourism Village, it is necessary to do several things including:

a. Expanding tourist areas and tourist attractions in Lebakmuncang Village because there are still many potentials that can still be developed.

b. Adding facilities in tourist areas such as information service centers and places to buy souvenirs.

c. Increasing education to the local community also includes environmental conservation activities and conservation activities in tour packages.

d. Increase promotion on social media.

\section{REFERENCES}

Badan Pusat Statistik (BPS) and Pusat Data and Informasi (Pusdatin) Kementerian Pariwisata. (2018). Laporan Akhir: Kajian Dampak Sektor Pariwisata Terhadap Perekonomian Indonesia. Jakarta: Fakultas Ekonomi dan Bisnis, Universitas Indonesia.

DISPARBUD. (2018). Pedoman Pengelolaan Desa Wisata. Jakarta: Dinas Pariwisata dan Kebudayaan.

Firdausyah, I. (2017). Analisis Status Keberlanjutan Wisata Pantai Sembilan Di Desa Bringsang, Kecamatan Giligenting, Kabupaten Sumenep, Madura, Jawa Timur. Malang: Universitas Brawijaya.

Ismayanti. (2010). Pengantar Pariwisata. Jakarta: PT Gramedia Widiasarana Indonesia.

Junaedi, I. W. R., \& Utama, I. G. B. R. (2017). Agrotourism as the economics transformation of the tourism village in Bali (case study: Blimbingsari Village, Jembrana, Bali). Journal of Business on Hospitality and Tourism, 2(1), 10-24.

Kamal, M., \& Suhirman. (2019). Strategi Pengembangan Desa Wisata Lebakmuncang Di Kabupaten Bandung Dengan Menggunakan Analisis Stakeholder.

Kristiana, Y., \& Theodora, S. (2018). trategi upaya pengembangan pariwisata berkelanjutan agrowisata berbasis masyarakat kampung domba terpadu Juhut, Provinsi Banten. Jurnal Ilmiah Widya, 4(3).

Maesari, N. (2018). Pengembangan Wisata Edukasi Berkelanjutan di Museum Geologi. Bandung: Universitas Padjadjaran.

PPID Distanhor Jabar. (2019). Pengembangan Potensi Agrowisata menjadi Destinasi Unggulan di Jawa Barat. Retrieved from distan.jabarprov.go.id: http://distan.jabarprov.go.id/distan/blog/detail/5127-pengembangan-potensi- 
agrowisata-menjadi-destinasi-unggulan-di-jawa-barat

Putri, A. W. (2017). Menjadikan Pariwisata sebagai Core Business Indonesia. Retrieved from https://swa.co.id/wicf/news/menjadikan-pariwisata-sebagaicore-business-indonesia

Riduwan. (2007). Skala Pengukuran Variabel-Variabel Penelitian. Bandung: Alfabeta.

Sugiyono. (2013). Metode Penelitian Kuantitatif, Kualitatif dan R\&D (13th ed.). Bandung: Alfabeta.

Syamsu, Y. (2001). Penerapan etika perencanaan pada kawasan wisata, studi kasus di kawasan agrowisata salak pondoh, Kabupaten Sleman, Daerah Istimewa Yogyakarta. Jurnal Ilmiah, 5(3).

Umar, H. (2005). Metode Penelitian Untuk Tesis Dan Bisnis. Jakarta: Grafindo.

Utama, I. G. (2004). Etika Pengembangan Agrowisata pada Kawasan Sekitar Taman Wisata Alam Danau Tamblingan. Denpasar: Universitas Dhyana Pura. 